\title{
Did Accession to the EU Affect Small and Large Firms Differently? The Case of the Austrian Retail and Wholesale Sector
}

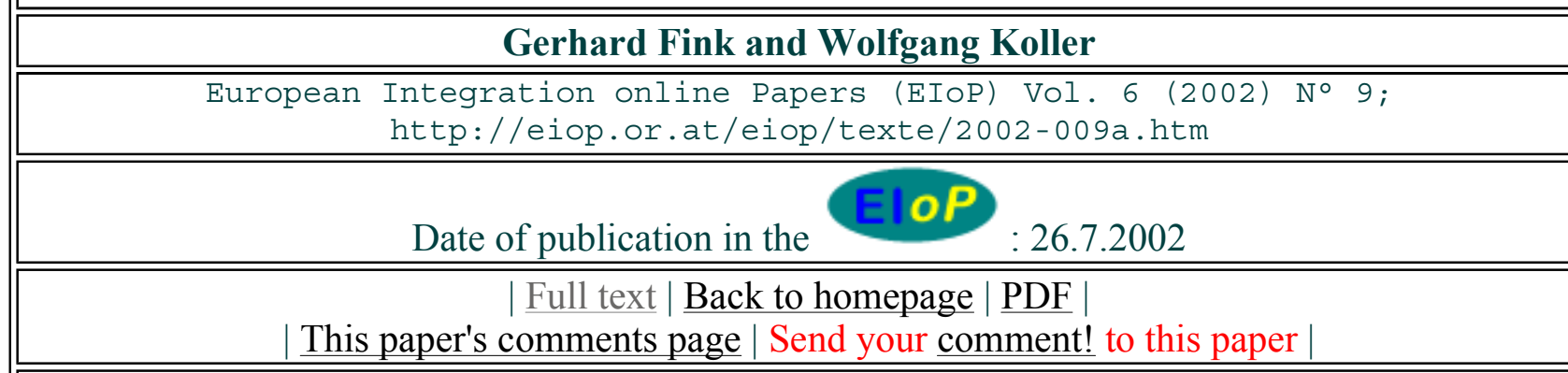

Keywords

economics, economic integration, economic performance, Austria, liberalization (JEL: D2, G3, L8)

\section{Abstract}

This paper presents an analysis of the effects that Austria's accession to the EU had on several key financial ratios of small business firms in the retail and wholesale trade sectors. These two industries were selected because before 1995 they were protected in many respects, thus vulnerable to increased competition after accession. The financial ratios selected are cash-flow per employed person, mean absolute deviation of cash-flow per employed person (as a variation-based risk measure), debt per employed person and financing cost as percentage of external debt. Together these four ratios determine a firm's creditworthiness. Our study is unique in that it is based on micro data, which allows us to consider the whole distribution of the ratios as compared to only aggregates as in other studies and to examine the scale effects within idustries. The data basis are balance sheets of more than 14,000 retail and 8,000 wholesale trade firms of all size classes during 1989-1996. In the empirical analysis we test the hypothsis of a structural break in the year of Austria's accession to the EU and put particular emphasis on the question whether small and large firms were affected differently by that structural break.

\section{Kurzfassung}

Es werden die Auswirkungen des Beitritts Österreichs auf den Einzelhandel und Großhandel anhand der Entwicklung ausgewählter Unternehmenskennzahlen untersucht, wobei die systematischen Unterschiede zwischen den Unternehmensgrößen besonders herausgestellt werden. Die beiden Sektoren sind deshalb exemplarisch, weil sie vor 1995 in vielerlei Hinsicht geschützt waren und durch den EU-Beitritt besonders einem verstärktem Wettbewerb ausgesetzt waren. Die ausgewählten Kennzahlen sind der Cash-Flow je Beschäftigten, die Mittlere Absolute Abweichung des Cash-Flows je Beschäftigten, die Verschuldung je Beschäftigten und die Finanzierungkosten. Diese vier Größen bestimmen zusammen die Kreditwürdigkeit eines Unternehmens. Durch die Verwendung von Mikro-Daten können im Rahmen der statistischen Untersuchung zusätzlich zu Aggregaten wie in anderen Studien auch Verteilungsaspekte und Größeneffekte berücksichtigt werden. Als Datenbasis dienen die Jahresabschlußdaten von mehr als 14.000 Einzelhandels- und 8.000 Großhandelsunternehmen im Zeitraum 1989 bis 1996. Wir führen statistische Tests auf einen Strukturbruch im Jahr des österreichischen EU-Beitritts durch und untersuchen, ob davon große und kleine Unternehmen unterschiedlich betroffen waren.

\section{The authors}

Univ.-Prof. Dkfm. Dr.Gerhard Fink is Jean Monnet Professor and chairman of the Research Institute for European Affairs (IEF) at the Vienna University of Economics and Business Administration; email: gerhard.fink@wu-wien.ac.at; Mag.Wolfgang Koller works as his research assistant; email: wolfgang.koller@wu-wien.ac.at. 


\section{Did Accession to the EU Affect Small and Large Firms Differently? The Case of} the Austrian Retail and Wholesale Sector(*)

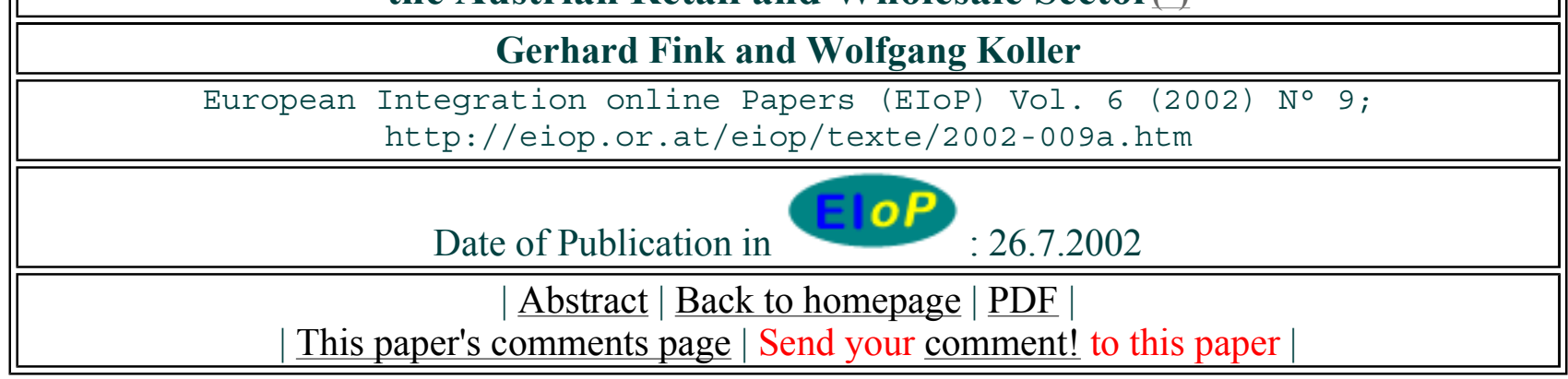

\section{Contents:}

- 1 Introduction

- 2 Theoretical Background

- 3 Formulation of Hypotheses

- 4 Data and Method

- 5 Results and Discussion

- 6 Conclusions

- References

\section{Introduction}

Austria's accession to the European Union in 1995 marked a thorough change in its economic development. There is wide agreement that among the effects of accession to the EU were a) more severe competition due to liberalisation and internationalisation of hitherto protected markets and $b$ ) better access of firms to finance because of more competition in banking, more open financial markets and diffusion of new financing instruments. While beneficial to the overall economy and to the consumer, it is not so clear what this meant for particular industries, size segments, or individual firms. Increased competition, for example, was mirrored by soaring numbers of insolvent firms and capital loss due to insolvencies (Breuss, 2000). Contrastingly, easier and cheaper access of firms to finance, should have improved the performance of firms.

In the present paper we focus on retail and wholesale trade, two sectors of the economy that were most directly affected by the accession to the EU(1). Before 1995 the trade sector was protected by a host of regulations, whose abrogation produced a strong pressure to adapt prices in accordance with international prices. These tendencies were not symmetric, i.e. opportunities to raise prices (those previously regulated down) were not as promptly used as price reductions (Pollan, 1998).

Thus, it seems that opportunities and threats created by Austria's accession to the European Union were not equally distributed.

The retail and wholesale trade sector contain firms of all size classes, competing with each other. All kinds of scale effects are present, particularly in the form of buying power (i.e. the ability to control suppliers due to large market shares) and selling power (i.e. the ability to control competitors and consumers by use of distribution channels which are only available to large firms) (Aiginger et al., 1999). 
In this paper we develop and test the hypothesis of differential effects of EU-accession on small and large firms. In comparison, have small or large firms been better off after 1995? Drawing on economic theory and on common sense we make predictions about the economic consequences of the year 1995 for small firms relative to large firms.

Our paper is unique in that it follows a micro aproach and uses data from a large database of 14,374 retail trade and 8,286 wholesale trade firms of all size classes. By using information on the whole distribution of firms our methodological setup allows conclusions on a representative firm of any size, not just about an average size firm or an aggregate of firms. The statistical analysis is based on four variables: firm-performance in terms of cash flow, a variation-based risk measure, financing cost and debt. Together these four variables determine creditworthiness.

The remainder of the paper is organized as follows. The next section motivates the selection of the four firm ratios and briefly reviews the theoretical literature relevant for our approach. The third section formulates the hypotheses. The fourth section describes the data and methods used. The fifth section presents and discusses the results followed by conclusions.

\section{Theoretical Background}

Management literature on performance analysis of business firms stresses that not only the performance in terms of profitability or productivity is relevant but also the risk which is taken in order to reach profitability targets. From two assets yielding the same expected returns a rational investor will prefer the one with the lower risk. Though this is an undisputed starting premise, studies that include comparisons of business firms with respect to some risk measure are still relatively new. It turned out to be somewhat controversial to transfer risk concepts derived from financial markets and related models (CAPM) to the performance measurement of business firms (Ruefli et al., 1999). Among other reasons, variation-based risk measures in the field of performance measurement were criticized (Miller and Leiblein, 1996) because they imply a symmetric risk concept, while in reality management is affraid only of negative movements. Nevertheless, it has become an accepted procedure to measure risk by means of the variation of profitability or other ratios of firm success.

Creditworthiness can be defined as the probability that a firm's true (present) value is not negative:

$$
C r=\operatorname{Pr}(V>0)
$$

where $V$ denotes the firm value. The link between a variation-based risk concept and creditworthiness can be established as follows. The value of the firm can be defined as

$$
V=-D+\sum_{t=1}^{\infty} C F_{t}(1+r)^{-t}
$$

where $D$ is the debt of the firm, $C F_{t}$ is the cash flow in future time points $t=1,2, \ldots$, and $r$ is an appropriate discounting rate. Given that in time $t=0$ the debt $D$ is known and assuming $r$ is constant over time, one can see that the distribution of $V$ depends on the distribution(s) of $C F_{t}$. Simplifying the 
relationship between $C F_{t}$ and $\operatorname{Pr}(V>0)$, it can be said that if the cash flows are positive on average the creditworthiness of a firm is negatively related to the variation of the cash flows. A certain positive cash flow given, it is also intuitively clear that the probability of a negative shock increases with higher variation in the cash flows to be large enough to endanger firm survival.

Equations (1) and (2) show that the creditworthiness of a firm is negatively related to the firm's debt and negatively related to the discounting rate (assuming positive cash flows). A good candidate for the discounting rate in equation (2) is the average or marginal credit interest rate of the firm or its financing cost. This is largely determined by the general level of interest rates but also by market conditions and risk perceptions of lenders.

This discussion illustrates the need to complement the conventional risk-return approach with two additional financial ratios. A broader concept of creditworthiness has to consider ratios of the indebtedness and financing cost of a firm in addition to cash flow performance and a variation based risk measure.

There is a long history of research efforts on the relationship between firm size and several relevant firm ratios. Often, predictions of a certain relationship between firm size and firm characteristics can be seen as a byproduct of some branch of industrial economics or of the theory of the firm. For example, arguments in the traditional line of the strategy-conduct-performance paradigm suggest that large firms are superior in performance to smaller firms because they have more influence on the competitional forces (Hall and Weiss, 1967). The German-speaking tradition of management science has developed a theory of the firm that sees the central function of management in simultaneously increasing profitability and reducing income uncertainty. This suggests that larger firms are superior with respect to both income and risk performance because they are more professionally managed than smaller firms (Schneider, 1993).

Other theories that successfully refute the Modigliani-Miller theorem about the irrelevance of the capital structure of the firm and stress notions of imperfect capital markets and information asymmetries between capital lenders and borrowers relate to the other two firm characteristics that interest us here: financing cost and debt. This research generally comes to the result that smaller firms, in comparison with large firms, rely more on borrowed capital, are disadvantaged in the capital markets and may face credit rationing and higher financing cost (for example López-Gracia and Aybar-Arias, 2000).

Previous empirical results are mixed on the relationship between firm size and firm performance, depending very much on the used size and performance measure (assets, sales, employment, profitability, cash flow ratios), time period and industry considered in the sample. When size is measured by employed persons large firms are generally superior to small firms with respect to risk (Fink et al., 2000). Finally, the greater importance of borrowed capital and higher financing cost for small firms as compared to large firms are well-known facts among practitioners. Fink and Koller (2001) show that per-capita-debt and financing cost regularly fall with firm size, thus reconfirming the need to see the four ratios as conditioning each other in a way that is connected to firm size. Taking these findings together we argue that performance, risk, debt and financing cost have to be considered together.

\section{Formulation of Hypotheses ${ }^{\uparrow}$}

Against this theoretical background we formulate a general hypothesis that the relationships between 
firm size and the ratios for performance, risk, financing costs and debt, were affected by Austria's accession to the European Union. We expect that the following changes in the relationships between firm size as measured by the number of employed persons and the four firm ratios took place:

a) cash flow performance and size: EU-accession radically changed retail and wholesale markets, in the food sector in particular. Since larger firms have more opportunities to exploit the chances of larger markets and are better equipped to cope with stronger price competition we can formulate

Hypothesis 1: Small firms in wholesale and retail trade were negatively affected by Austria's accession to the EU.

b) cash flow risk and size: If firms (small firms in particular) were negatively affected by EU accession risk would increase if in a given size class firms with above average cash flow would be less affected than firms with below average cash flow performance. Since we had argued before that cash flow performance could have been negatively affected because of increased competition, we have to assume that risk has not changed because of accession. We could add a caveat, that if in all size classes poorly performing firms would have gone bankrupt and thus disappeared from the sample, that we could at best expect a small reduction in risk.

Hypothesis 2: Since in a given size class all firms are affected in a similar vein by EU accession, risk remains unchanged after accession.

c) Financing cost and size: We argue that due to liberalisation of financial markets all firms had more easy access to finance. Larger firms may have had even better opportunities than small firms. Furthermore, financing cost also reflect to some degree the creditworthiness of the firm as rated by banks. In the light of diminishing cash flow performance and thus creditworthiness of small firms (Hypothesis 1), this reinforced the tendency of larger firms having lower financing costs than small firms.

Hypothesis 3: Financing cost of all firms fell after accession, however, more strongly for larger than for smaller firms.

d) Per capita debt and size: From equation (2) it follows that a firm's creditworthiness is declining as cash flow is declining. Furthermore, an analogue relationship between financing cost and debt exists in that lower financing costs allow firms to raise more credit. Thus, as a consequence of Hypothesis 1 we have to assume that the capacity of firms to raise credit was declining after EU accession. However, given Hypothesis 3, this tendency might be alleviated by lower financing cost, especially in the larger size classes.

Hypothesis 4: In those size classes where cash flow was negatively affected by EU accession and where the reduction of financing cost was less pronounced per capita debt had to be reduced.

\section{Data and Method}

The statistical analysis is based on a large sample of Austrian firms from the retail and wholesale trade sectors for the period 1989-1996. Tables 1 and 2 provide an overview over the size and composition of the data sample.

\section{Table 1}

As already mentioned the sample covers 14,374 and 8,286 firms, respectively, of all size classes. Furthermore Table 2 presents basic facts on the size distribution of the two sectors as observed in the 
„real world“, thus allowing an assessment of the representativity of the data. Despite the large share of small firms in our sample, very small firms (less than 10 employed persons) are still somewhat underrepresented as compared with the size distribution observed in the real world.

Table 2

The raw data encompass several ratios derived from the annual financial statements of firms. Originally, these data were provided by the firms to banks, mainly in the course of applications for new credit or credit extensions, but also to consulting and auditing firms. The „Institut für Gewerbeund Handelsforschung" (IfG), a small-business-research institution in Austria and our provider of the data, collected the data, secured data quality, among other things by eliminating double counts and introducing corrections for employers' salaries, and augmented the data by further information such as number of employed persons and industry and region codes.

From this data base we derived the following ratios: (1) cash flow / Employed Person, (2) Total Debt / Employed Person, (3) Financing Cost / External Debt. Here cash flow is recalculated as result of ordinary operations + depreciation + calculatory cost for own capital; total debt is defined as external debt (liabilities) + internal debt (accruals for pensions and severance payments). Using a price deflator (source: Austrian Institute for Economic Research, WIFO) all ratios are transformed into prices of 1996.

The use of the number of employed persons as the denominator of the ratios and as a measure of firm size was suggested by theoretical and practical reasons. Employment as a size measure has the theoretical advantage that it cannot be viewed as a measure of performance in itself, like other measures of firm size such as sales or own capital, see Fink et al. (2000). While sales is an output variable, performance measurement requires an input variable as denominator and independent variable. Also own capital can be viewed as measure of performance rather than size, since it reflects the accumulated cash flows of previous years. From a practical point of view, employment as a measure of size brings robustness to the data, since it cannot be negative. Approximately 50 percent of the firms in the sample have negative own capital, ruling out own capital and total assets as denominator and independent variables for practical reasons.

Table 3 summarizes the three ratios formed. The often considerable gap between mean and median values hints at the skewness present in some of the distributions. Also, by comparing the statistics across size classes one can see that within-size-class variation generally exceeds between-size-class variation.

\section{Table 3}

The construction of a variation-based measure of firm risk along the lines followed by most of the empirical studies of the risk-return tradition (Ruefli et al. 1999) requires a procedure that involves grouping of individual firms together. Cross-section variation within groups provides us with a measure of risk. In detail the procedure is the following: Within each of the two industries, within each of the two regional subdivisions and separately for each year we ranked firms according to size (number of employed persons including self-employed) and formed groups of $k=9$ firms of the same or adjacent size. The value $k=9$ was chosen as a compromise between the goals of having enough group members within each group and having enough groups/data points in the subsequent regression analysis. The mean absolute deviation (MAD) of the cash flow per employee between the group members was then taken as a measure of risk. Grouping procedures in combination with regression analysis based on summary statistics of the constructed groups are a well-established 
method (Grunfeld and Griliches, 1960; Maddala, 1977).

The use of cross-section variation for calculating risk measures is a relatively new research method. It can be seen as approximation of the more conventional time-series variation-based risk measure. The validity of this approximation was verified by us for a sub-sample of firms with time series data. A comparison of the size dependence of time-series based risk with cross-section based risk revealed great similarities. But note that from the point of view of a bank or lender who is assumed to know only the size of a credit applicant firm a cross-section variation-based risk measure is justified in its own right.

Based on the grouping procedure we formed a set of four dependent variables and one explanatory variable: $C F P$ (cash flow-Performance), ln CFR (cash flow-Risk, in Logs), LND (Indebtedness), FNC (Financing Costs) and ln Size (Firm Size, in Logs), defined as:

CFP = Group-Median (cash flow/Employed Persons)

$\ln C F R=\ln$ Group-Mean-Absolute-Deviation (cash flow/Employed Persons)

$L N D=$ Group-Mean ( $\ln$ (Total Debt / Employed Persons)

$F C O=$ Group-Median (Financing Cost $/$ External Debt)

$\ln$ Size $=\ln$ Group-Mean (Employed Persons)

Using the median for $C F P$ and $F C O$ and the mean absolute deviation for $C F R$ instead of the mean and standard deviation, respectively, implies an inherent robustification against outliers in the raw (ungrouped) data. In constructing $L N D$ we took logarithms prior to forming the group-mean, motivated by the distributional properties of this ratio. The distribution of total per-capita debt, conditional on firm size and industry, can very well be approximated by a lognormal distribution. Results with the Kolmogorov-Smirnov test, that confirm this approximation assumption, are reported in Fink and Koller (2001). The decision to use CFR and Size in their log-transformed form resulted from the search for correct specification in the regression analysis.

Furthermore, we made an attempt to control for other effects which may vary in our sample over the years, such as size distribution and regional composition. We did this by modeling the dependent variable as a polynomial function of the size variable ( $\ln$ Size) and by introducing dummy variables that account also for geographical location of the firm, as we cannot exclude that the financing conditions for firms in urban areas, where the density of bank subsidiaries and thus competition is high, is different from that in rural areas.

We test the main hypothesis by testing a basic model of the relationship between firm size and the firm ratio against an extended model that allows for a structural break in this relationship, thus accomodating the possible differential effect that accession to the EU might have had on small and micro firms as opposed to larger firms. Each model is estimated on each of the two industries and on each of the four firm ratios as dependent variables. The basic (restricted) model is given as

$$
C F P=\alpha+\beta_{1} X+\mathrm{K}+\beta_{m} X^{m}+\sum_{j l}^{*} \phi_{j l} D_{j l}+\varepsilon
$$




$$
\begin{aligned}
& \ln C F R=\alpha+\beta_{1} X+\mathrm{K}+\beta_{m} X^{m}+\sum_{j l}^{*} \phi_{j l} D_{j l}+\varepsilon \\
& L N D=\alpha+\beta_{1} X+\mathrm{K}+\beta_{m} X^{m}+\sum_{j l}^{*} \phi_{j l} D_{j l}+\varepsilon \\
& F C O=\alpha+\beta_{1} X+\mathrm{K}+\beta_{m} X^{m}+\sum_{j l}^{*} \phi_{j l} D_{j l}+\varepsilon
\end{aligned}
$$

where for brevity we write $X$ for $\ln$ Size. $D_{j l}$ are the dummy-variables accounting for time and region effects. $D_{j l}$ assumes the value of 1 for data entries corresponding to both year $j$ and region $l$ and otherwise the value of 0 . e is an error term. The asterisk above the sum sign indicates that for reasons of collinearity exactly one of the combinations of $j$ and $l$ has to be excluded from the regression equation (Kennedy, 1998, chapter 14). In the modelling procedure we left the specification of the order $m$ of the polynomial in $X$ up to the data, adding a new $X^{i}$ only when its coefficient was statistically significant at a confidence level of $5 \%(t$-test).

The extended (unrestricted) model has the form

$$
\begin{aligned}
& C F P=\alpha+\beta_{1} X+\ldots+\beta_{m} X^{m}+\gamma_{1} Y+\ldots+\gamma_{n} Y^{n}+\sum_{j l}^{*} \phi_{j l} D_{j l}+\varepsilon \\
& \ln C F R=\alpha+\beta_{1} X+\ldots+\beta_{m} X^{m}+\gamma_{1} Y+\ldots+\gamma_{n} Y^{n}+\sum_{j l}^{*} \phi_{j l} D_{j l}+\varepsilon \\
& L N D=\alpha+\beta_{1} X+\ldots+\beta_{m} X^{m}+\gamma_{1} Y+\ldots+\gamma_{n} Y^{n}+\sum_{j l}^{*} \phi_{j l} D_{j l}+\varepsilon \\
& F C O=\alpha+\beta_{1} X+\ldots+\beta_{m} X^{m}+\gamma_{1} Y+\ldots+\gamma_{n} Y^{n}+\sum_{j l}^{*} \phi_{j l} D_{j l}+\varepsilon
\end{aligned}
$$

where the construction of the new variable, $Y=D_{95 / 96} X$, involves the dummy variable $D_{95 / 96}$ that in the years 1995 and 1996 takes on the value of 1 and 0 otherwise. Specification of the model order $n$ of the polynomial in $Y$ was $n=m$ if $m>0$ and $n=1$ if $m=0$.

An explicit test of our hypothesis of the differential effect of accession to the EU on small and large firms can now be formulated as a Chow-test

$$
\text { Chow }=\frac{\left(S S E_{1}-S S E_{2}\right) / J}{S S E_{2} /(T-K)}
$$


where $S S E_{1}$ is the sum of sqared errors of the (restricted) model $\underline{3 a}$ (or 3b, 3c, 3d, respectively), $S S E_{2}$ is the sum of squared errors of the (unrestricted) model $4 \mathrm{a}$ (4b, 4c, 4d, respectively), $J$ is the number of tested restrictions, $T$ is the number of observations and $K$ is the number of regressors in the unrestricted model, including the intercept. The test statistic is $F$-distributed with $J$ and $(T-K)$ degrees of freedom.

While estimation of the Models $3 b-3 d$ and $4 b-4 d$ was done with OLS, for models $3 a$ and $4 a$ weighted least squares (WLS) was used in order to account for the considerable heteroskedasticity of the dependent variable, $C F P$, in this case. As evidenced by the results from model $3 \mathrm{~b}$ and $4 \mathrm{~b}$ heteroskedasticity of $C F P$, conditional on firm size, is an inherent feature of the data. Indeed, we are able to use the predicted measures of variation derived from model $\underline{3 b}$ as weights in the WLS estimation procedure. This is possible because there is a direct conceptual link and a high empirical correlation between $C F R$ and the conditional standard deviation of the residuals of model $3 \mathrm{a}$ and $4 \mathrm{a}$.

\section{Results and Discussion}

Before presenting the evidence on the formulated hypotheses we give an overview on the development of cash flow performance over the years 1989-1996.

\section{Figure 1}

In Figure 1 it can be seen that the two industries have different levels of median cash flow per employed person (2). However, in both cases and also in the case of the overall economy, included in the graph for comparison purposes, we observe a decline in cash flow performance in the year 1995. A similar analysis of the other ratios yields no special pattern for the years 1995 and 1996, suggesting no relevant effects of the accession to the EU on the aggregated level of the industry.

Formal testing of the hypothesis with the help of the Chow test yields the results presented in Table 4.

Table 4

In 1995 structural breaks in the scale effects occured in five out of eight cases. The Chow test yields particularly strong evidence of a structural break for cash flow performance and financing costs. Furthermore in the wholesale trade industry the test result indicates changing scale effects for percapita debt (Table 4).

In the following we discuss the results of model $3 a-3 d$ as compared with $4 a-4 d$, focussing on these five specific cases. Table 5 and 6 summarize these estimated statistical results, including only that model that was favoured by the Chow test.

\section{Table 5}

\section{Table 6}

For cash flow performance our results clearly demonstrate that together with Austria's accession to the EU went a considerable detoriation of the situation of small and micro firms. In both industries a representative one-person firm had to face a reduction of cash flow (per employed person) of about 50,000 ATS. Only firms above a size of about 50 employed persons seemed unaffected by the 
changing economic environment (Figure 2)(3)

Figure 2

The estimated scale effects for cash flow risk seem to be stable over time. No structural break occured in 1995. Thus, with respect to our risk measure, Austria's accession to the EU did not affect small and large firms in different ways. It is, however, worthwile to note that large firms are subject to significantly smaller risk (Figure 3).

\section{Figure 3}

For financing costs, our analysis reveals a clear relative advantage of larger firms over smaller firms after 1995. Though large firms had considerably lower financing cost before 1995, this gap has widened by between 0.5 and 0.8 percentage points, as seen from a comparison of a one-person firm with a 100-person firm in the both industries. This development is directly and indirectly linked to Austria's accession to the EU. Due to higher bargaining power vis-a-vis lending banks larger firms are supposed to benefit sooner from falling interest levels. Relatively higher interest rates (in comparison with large firms) reflect to some degree the lower creditworthiness of small firms, that came along with Austria's accession to the EU, as unveiled above by the analysis of cash flow performance (Figure 4).

\section{Figure 4}

A similar characterisation applies to per-capita debt. Its functional dependence on size seems to be stable over time. In the case of wholesale trade there is statistical evidence for a structural break. A plausible explanation for the differences in scale effects between the pre-EU and post-EU period is that lower cash flow is reducing the creditworthiness of firms. Existing firms had to adjust their debt levels and those firms that were most indebted were driven out of the market by the higher competitve pressures. This effect resulted in a smaller debt burden of the small and micro firm sector after 1995 (Figure 5).

\section{Figure 5}

\section{Conclusions}

In this paper we applied methods of performance measurement, as used in management science, in order to find out about the possible differential effects of Austria's accession to the EU when comparing small firms with large firms. The analysis considered four firm characteristics, cash flow performance, cash flow risk, per-capita debt and financing costs, that together determine the creditworthiness of the firm. cash flow risk was measured by the variaton of cash flow per employed person.

In the main, the results confirm the hypotheses we formulated in section 3 . Austria's accession to the EU had a very different impact on small and large firms with the respect to the most important firm ratios. Both industries faced problems of cash flow-performance due to the shock of deregulation and increased competition. With respect to cash flow risk our analysis indicated that small and large firms were not differently affected.

Small and large firms have lower financing costs in 1995/96. However, small firms' financing costs 
fell less than that of large firms after the year 1995. This may be connected to the disadvantages that small firms have in the new environment of more liquid capital markets and more competition among banks. But it may also reflect that banks charge relatively higher interest rates, in view of poorer cash flow performance of small retail and wholesale trade firms.

For per capita debt (only in the wholesale trade industry) we could show that small firms were affected by the accession to the EU and had to reduce their per capita debt.

Our analysis indicates that in a comparison of small and large firms before and after Austria's accession to the EU the most influential change concerned the cash flow performance of firms. Significant changes in the other ratios (per capita debt, financing costs) seem to be at least partly a consequence of changes in the cash flow performance.

\section{References $^{\uparrow}$}

Aiginger, K., R. Wieser, and M. Wüger (1999): Marktmacht im Lebensmitteleinzelhandel. Monatshefte des Österreichischen Instituts für Wirtschaftsforschung 72(12), 797-809

Breuss, F. (2000): An evaluation of the economic effects of Austria's EU membership. Austrian Economic Quarterly 5(4), 171-196

Fink, G. and W. Koller (2001): Die Kreditwürdigkeit von Unternehmen im Hinblick auf die Wirtschafts- und Währungsunion - Wien im österreichischen Vergleich. IEF Working Paper 41 $<$ http://fgr.wu-wien.ac.at/institut/ef/wp/WP41.pdf $>$

Fink, G., M. Oppitz and D. Salvatore (2000): A Test on the Superiority of Large Firms as Institutions to Reduce Income Risks. Zeitschrift für Betriebswirtschaft 70(4), 453-470.

Grunfeld, Y. and Z. Griliches (1960): Is Aggregation Necessarily Bad?, Review of Economics and Statistics 42(1), 1-13.

Hall, M. and L. Weiss (1967): Firm Size and Profitability. Review of Economics and Statistics 49(3), 319-331

Kennedy, P. E. (1998): A Guide to Econometrics. MIT Press, Cambridge MA

López-Gracia, J. and C. Aybar-Arias (2000): An Empirical Approach to the Financial Behaviour of Small and Medium Sized Companies. Small Business Economics 14(1), 55-63

Maddala, G. S. (1977): Econometrics. New York, McGraw-Hill

Miller, K.D. and M. J. Leiblein (1996): Corporate Risk-Return Relations: Returns Variability versus Downside Risk. Academy of Management Journal, 39(1), 91-122

Pollan, W. (1998): Große Preisunterschiede zwischen Einzelhandelsgeschäften. Monatshefte des Österreichischen Instituts für Wirtschaftsforschung 71(9), 627- 637

Ruefli, T. W., J. M. Collins and J. R. Lacugna (1999): Risk Measures in Strategic Management Research: Auld Lang Syne? Strategic Management Journal 20(2), 167-194.

Schneider, D. (1993): Allgemeine Betriebswirtschaftslehre, Band 1. Oldenbourg, München 


\section{Endnotes}

(*) The authors gratefully acknowledge the support of this work by the Wirtschaftsuniversitätspreis der Wirtschaftskammer Wien and by the Jubiläumsfonds der Oesterreichischen Nationalbank. Thanks are due to Fritz Breuss for comments and to the R community (http://www.r-project.org/) for providing a wonderful, freely available tool for statistical computations.

(1) Results on other sectors as well as a more detailed description on some methodological issues can be found in Fink and Koller (2001).

(2) The values presented in Figure 1 are derived from estimated model $3 \mathrm{a}$, using a weighted average of the intercept and the coefficients with the dummy variables $D_{j l}$ such that the levels of the starting year are calibrated to correspond with the median firm.

(3) Figures 2-5 contain a graphical representation of the functional dependence of the four indicators on firm size, as it is implied by the favoured model. In the case of statistical significance of the Chow statistic model $4 \mathrm{a}, 4 \mathrm{~b}, 4 \mathrm{c}$ or $4 \mathrm{~d}$, respectively, was used for the calculation of the lines, otherwise models 3a, 3b, 3c or 3d. For each of the two periods, 1989-1994 and 1995-1996 a line is included in the plots. 


\section{Table I}

\section{Sample size, number of data entries by year, 1989 - 1996}

\begin{tabular}{|l|l|l|l|l|l|l|l|l|l|l|}
\hline \multicolumn{1}{|c|}{} & 1989 & 1990 & 1991 & 1992 & 1993 & 1994 & 1995 & 1996 & total \\
\hline Retail Trade & 2149 & 2121 & 1134 & 1051 & 1645 & 1111 & 2761 & 2402 & 14374 \\
\hline \hline Wholesale Trade & 1452 & 1341 & 942 & 690 & 820 & 720 & 1234 & 1087 & 8286 \\
\hline \hline
\end{tabular}

\section{Table II}

\section{Comparison of sample and real-world size distributions, number of firms and employment by size classes, 1995}

\begin{tabular}{|c|c|c|c|c|c|c|}
\hline & 1 - 4 emp. & 5 - 9 emp. & 10 - 19 emp. & 20 - 99 emp. & $>100 \mathrm{emp}$ & total \\
\hline \multicolumn{7}{|l|}{ Retail Trade: } \\
\hline number of firms (sample)* & $\begin{array}{r}1,411 \\
(51.1) \\
\end{array}$ & $\begin{array}{r}557 \\
(20.1) \\
\end{array}$ & $\begin{array}{r}375 \\
(13.6) \\
\end{array}$ & $\begin{array}{r}355 \\
(12.9) \\
\end{array}$ & $\begin{array}{r}63 \\
(2.3) \\
\end{array}$ & $\mid \begin{array}{r}2,761 \\
(100.0) \\
\end{array}$ \\
\hline employment (sample) & $\begin{array}{r}3,125 \\
(7.9) \\
\end{array}$ & $\begin{array}{r}3,679 \\
(9.3) \\
\end{array}$ & \begin{tabular}{r|}
5,049 \\
$(12.7)$ \\
\end{tabular} & $\begin{array}{r}13,957 \\
(35.3) \\
\end{array}$ & \begin{tabular}{r|}
13,733 \\
$(34.7)$ \\
\end{tabular} & \begin{tabular}{|c}
39,543 \\
$(100.0)$ \\
\end{tabular} \\
\hline employment (real-world) $* *$ & $\begin{array}{r}65,323 \\
(19.9) \\
\end{array}$ & $\begin{array}{r}48,455 \\
(14.7) \\
\end{array}$ & \begin{tabular}{r|}
41,929 \\
$(12.7)$ \\
\end{tabular} & \begin{tabular}{r|}
56,905 \\
$(17.3)$ \\
\end{tabular} & $\begin{array}{r}16,336 \\
(35.4) \\
\end{array}$ & $\begin{array}{r}328,948 \\
(100.0)\end{array}$ \\
\hline \multicolumn{7}{|l|}{ Wholesale Trade: } \\
\hline number of firms (sample) & $\begin{array}{r}449 \\
(36.4) \\
\end{array}$ & $\begin{array}{r}253 \\
(20.5) \\
\end{array}$ & \begin{tabular}{r|}
195 \\
$(15.8)$ \\
\end{tabular} & $\begin{array}{r}278 \\
(22.5) \\
\end{array}$ & $\begin{array}{r}59 \\
(4.8) \\
\end{array}$ & $\begin{array}{r}1,234 \\
(100.0) \\
\end{array}$ \\
\hline employment (sample) & $\begin{array}{r}966 \\
(3.6) \\
\end{array}$ & $\begin{array}{r}1.728 \\
(6.2) \\
\end{array}$ & \begin{tabular}{r|}
2,709 \\
$(9.8)$ \\
\end{tabular} & $\begin{array}{r}12,081 \\
(43.8) \\
\end{array}$ & $\begin{array}{r}10,059 \\
(36.5) \\
\end{array}$ & \begin{tabular}{|c}
27,543 \\
$(100.0)$ \\
\end{tabular} \\
\hline employment (real-world) & $\begin{array}{r}23,205 \\
(12.0) \\
\end{array}$ & $\begin{array}{r}18,192 \\
(9.3) \\
\end{array}$ & $\begin{array}{r}22,338 \\
(11.5) \\
\end{array}$ & $\begin{array}{r}55,395 \\
(28.5) \\
\end{array}$ & $\begin{array}{r}75,420 \\
(38.7) \\
\end{array}$ & $\begin{array}{r}194,550 \\
(100.0) \\
\end{array}$ \\
\hline
\end{tabular}

* values in parentheses denote the percent shares

** real-world as observed according to Austrian Industrial Statistics (source: Statistik Austria) 


\section{Table III}

\section{Descriptive statistics of selected variables by size classes, 1995}

\begin{tabular}{|c|c|c|c|c|c|c|}
\hline \multicolumn{2}{|l|}{ 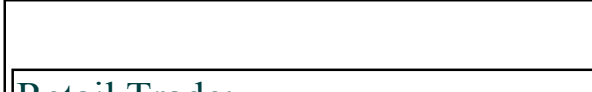 } & 1 - 4 emp. & 5 - 9 emp. & 10 - 19 emp. & 20 - 99 emp. & $>100 \mathrm{emp}$ \\
\hline \multicolumn{7}{|l|}{ Retail Trade: } \\
\hline $\begin{array}{c}\text { cash flow per employee } \\
(1,000 \text { ATS })\end{array}$ & $\begin{array}{r}\text { mean } \\
\text { median } \\
\text { 1st quart. } \\
\text { 3rd quart. }\end{array}$ & $\begin{array}{r}-38.0 \\
-38.0 \\
-148.0 \\
65.5\end{array}$ & $\begin{array}{r}36.0 \\
15.3 \\
-39.1 \\
85.3\end{array}$ & $\begin{array}{r}30.8 \\
25.2 \\
-26.6 \\
75.8\end{array}$ & $\begin{array}{l}44.2 \\
40.3 \\
-0.8 \\
88.4\end{array}$ & $\begin{array}{r}67.7 \\
61.9 \\
16.6 \\
103.5\end{array}$ \\
\hline $\begin{array}{l}\text { debt per employee } \\
\quad(1,000 \text { ATS })\end{array}$ & \begin{tabular}{|r} 
mean \\
median \\
1 st quart. \\
3 rd quart. \\
\end{tabular} & $\begin{array}{r}1,567.0 \\
1,101.0 \\
644.6 \\
1,897.0 \\
\end{array}$ & $\begin{array}{r}1,079.0 \\
839.6 \\
501.5 \\
1,252.0 \\
\end{array}$ & $\begin{array}{r}932.5 \\
729.3 \\
469.6 \\
1,163.0 \\
\end{array}$ & $\begin{array}{r}873.4 \\
715.2 \\
449.8 \\
1,077.0 \\
\end{array}$ & $\begin{array}{l}789.4 \\
745.2 \\
484.1 \\
913.2 \\
\end{array}$ \\
\hline $\begin{array}{l}\text { financing cost } \\
\text { (percent) }\end{array}$ & $\begin{array}{r}\text { mean } \\
\text { median } \\
1 \text { st quart. } \\
3 \text { rd quart. }\end{array}$ & $\begin{array}{l}8.0 \\
7.6 \\
5.9 \\
9.2 \\
\end{array}$ & $\begin{array}{l}7.7 \\
7.0 \\
5.5 \\
8.6\end{array}$ & $\begin{array}{l}7.3 \\
6.7 \\
5.1 \\
8.5 \\
\end{array}$ & $\begin{array}{l}7.0 \\
6.3 \\
4.9 \\
8.3 \\
\end{array}$ & $\begin{array}{l}6.6 \\
6.2 \\
4.4 \\
7.4\end{array}$ \\
\hline \multicolumn{7}{|l|}{ Wholesale Trade: } \\
\hline $\begin{array}{c}\text { cash flow per employee } \\
\text { (1,000 ATS) }\end{array}$ & \begin{tabular}{|r} 
mean \\
median \\
1 st quart. \\
3 rd quart. \\
\end{tabular} & $\begin{array}{r}235.5 \\
89.8 \\
-102.0 \\
398.0 \\
\end{array}$ & $\begin{array}{r}145.2 \\
73.5 \\
-35.0 \\
239.8 \\
\end{array}$ & $\begin{array}{r}138.1 \\
78.8 \\
-11.2 \\
253.8 \\
\end{array}$ & \begin{tabular}{r|}
109.8 \\
82.0 \\
8.6 \\
182.7 \\
\end{tabular} & $\begin{array}{r}134.8 \\
88.3 \\
40.7 \\
182.9 \\
\end{array}$ \\
\hline $\begin{array}{l}\text { debt per employee } \\
\text { (1,000 ATS })\end{array}$ & $\begin{array}{r}\text { mean } \\
\text { median } \\
1 \text { st quart. } \\
3 \text { rd quart. } \\
\end{array}$ & $\begin{array}{l}3,776.0 \\
1,981.0 \\
1,094.0 \\
4,115.0 \\
\end{array}$ & $\begin{array}{l}2,748.0 \\
1,681.0 \\
1,007.0 \\
2,943.0 \\
\end{array}$ & $\begin{array}{r}1,835.0 \\
1,339.0 \\
784.5 \\
2,420.0 \\
\end{array}$ & $\begin{array}{r}1,715.0 \\
1,218.0 \\
813.3 \\
2,002.0 \\
\end{array}$ & $\begin{array}{r}1,170.0 \\
940.1 \\
642.0 \\
1,358.0 \\
\end{array}$ \\
\hline $\begin{array}{l}\text { financing cost } \\
\text { (percent) }\end{array}$ & \begin{tabular}{|r|} 
mean \\
median \\
1 st quart. \\
3rd quart.
\end{tabular} & $\begin{array}{l}8.3 \\
7.1 \\
4.8 \\
9.8\end{array}$ & $\begin{array}{l}7.6 \\
6.9 \\
4.6 \\
9.2\end{array}$ & $\begin{array}{l}7.9 \\
7.0 \\
5.1 \\
9.1\end{array}$ & $\begin{array}{l}7.1 \\
6.4 \\
5.0 \\
8.3\end{array}$ & $\begin{array}{l}6.9 \\
6.1 \\
4.9 \\
8.4\end{array}$ \\
\hline
\end{tabular}




\section{Table IV}

\section{Results of the Chow test ( $F$-statistic) for a structural break in the relationship between firm size and selected variables}

\begin{tabular}{|c|c|c|c|c|c|}
\hline & $\begin{array}{c}\text { Cash-flow } \\
\text { performance } \\
(C F P)\end{array}$ & $\begin{array}{c}\text { Cash-flow } \\
\text { risk } \\
(C F R) \\
\end{array}$ & $\begin{array}{c}\text { Financing } \\
\text { costs } \\
(F C O) \\
\end{array}$ & $\begin{array}{c}\text { Per-capita } \\
\text { debt } \\
(L N D) \\
\end{array}$ & $\begin{array}{c}\text { Number of } \\
\text { observations } \\
(T)\end{array}$ \\
\hline Retail Trade & $\begin{array}{r}15.440 * * * \\
(0.000)\end{array}$ & $\begin{array}{r}1.166 \\
(0.321)\end{array}$ & $\begin{array}{r}10.656^{* *} \\
(0.001)\end{array}$ & $\begin{array}{r}2.074 \\
(0.102)\end{array}$ & 1592 \\
\hline WholesaleTrade & $\begin{array}{r}6.534 * \\
(0.011)\end{array}$ & $\begin{array}{r}1.740 \\
(0.176)\end{array}$ & $\begin{array}{r}8.094 * * \\
(0.004)\end{array}$ & $\begin{array}{r}10.148 * * * \\
(0.000)\end{array}$ & 914 \\
\hline
\end{tabular}

Note: values in parentheses are the prob-values of the $F$-statistic, which has $J$ and $(T-K)$ degrees of freedom, where $J$, the number of tested restriction depends on model specification and varies between 1 and $3, K$ is the number of regressors in the unrestricted model, accordingly varying between 18 and 22, and $T$ is the number of observations.

$* * *, * *, *$ denote statistical significance at confidence levels of $0.1,1$ and 5 percent.

\section{Table V}

\section{Results of Estimations for Retail Trade}

\begin{tabular}{|c|c|c|c|c|}
\hline Variable & $\begin{array}{c}\text { Cash-flow Performance } \\
(C F P)\end{array}$ & $\begin{array}{c}\text { Cash-flow Risk } \\
\text { (CFR) }\end{array}$ & $\begin{array}{c}\text { Financing Cost } \\
\text { (FCO) }\end{array}$ & $\begin{array}{c}\text { Per-capita Debt } \\
\text { (LND) }\end{array}$ \\
\hline$X$ & $\begin{array}{c}66.006 * * * \\
(0.0000)\end{array}$ & $\begin{array}{c}-0.804 * * * \\
(0.0000)\end{array}$ & $\begin{array}{c}-0.262 * * * \\
(0.0000)\end{array}$ & $\begin{array}{c}-0.559 * * * \\
(0.0000)\end{array}$ \\
\hline$X^{2}$ & $\begin{array}{c}-16.512 * * * \\
(0.0000) \\
\end{array}$ & $\begin{array}{c}0.157 * * * \\
(0.0000) \\
\end{array}$ & & $\begin{array}{c}0.151 * * * \\
(0.0000) \\
\end{array}$ \\
\hline$X^{3}$ & $\begin{array}{c}1.368 * * * \\
(0.0000) \\
\end{array}$ & $\begin{array}{l}0.011 * * \\
(0.0034) \\
\end{array}$ & & $\begin{array}{c}-0.015 * * \\
(0.0000) \\
\end{array}$ \\
\hline$Y=D_{95 / 96^{X}}$ & $\begin{array}{l}37.293 * * \\
(0.0056)\end{array}$ & & $\begin{array}{l}-0.145 * * \\
(0.0011)\end{array}$ & \\
\hline $\begin{array}{c}Y= \\
D_{95 / 96} X^{2}\end{array}$ & $\begin{array}{c}-8.707 \\
(0.1043)\end{array}$ & & & \\
\hline $\begin{array}{c}Y= \\
D_{95 / 96^{X}} X^{3}\end{array}$ & $\begin{array}{c}0.811 \\
(0.1971)\end{array}$ & & & \\
\hline$R^{2}$ adj. & 0.290 & 0.472 & 0.339 & 0.562 \\
\hline$F$ F-Stat & $31.940 * * *$ & $80.062 * * *$ & $48.950 * * *$ & $1114.440 * * *$ \\
\hline Num. Obs. & 1592 & 1592 & 1592 & 1592 \\
\hline Num.Coeff. & 22 & 19 & 18 & 19 \\
\hline
\end{tabular}

Note: values in parentheses are the prob-values of the $t$-statistic and $F$-statistic, respectively. Estimation results for the intercept and 15 dummy-variables for each year and region are not reported here. They are available in Fink and Koller (2001).

$* * *, * *$ and $*$ denote statistical significance at confidence levels of $0.1,1$ and 5 percent. 


\section{Table VI}

\section{Results of Estimations for Wholesale Trade}

\begin{tabular}{|c|c|c|c|c|}
\hline Variable & $\begin{array}{l}\text { Cash-flow Performance } \\
(C F P)\end{array}$ & $\begin{array}{c}\text { Cash-flow Risk } \\
\text { (CFR) }\end{array}$ & $\begin{array}{l}\text { Financing Cost } \\
\text { (FCO) }\end{array}$ & $\begin{array}{l}\text { Per-capita Debt } \\
\text { (LND) }\end{array}$ \\
\hline$X$ & $\begin{array}{c}-13.308 * * * \\
(0.0000)\end{array}$ & $\begin{array}{c}-0.476 * * * \\
(0.0000)\end{array}$ & $\begin{array}{c}-0.016 \\
(0.6659)\end{array}$ & $\begin{array}{c}-0.308 * * * \\
(0.0000)\end{array}$ \\
\hline$X^{2}$ & & $\begin{array}{c}0.032 * * * \\
(0.0001) \\
\end{array}$ & & $\begin{array}{l}0.015 * * \\
(0.0055) \\
\end{array}$ \\
\hline \multicolumn{5}{|l|}{$X^{3}$} \\
\hline$Y=D_{95 / 96} X$ & $\begin{array}{l}10.081 * \\
(0.0107) \\
\end{array}$ & & $\begin{array}{c}-0.198 * * \\
(0.0045) \\
\end{array}$ & $\begin{array}{l}0.145 * * \\
(0.0031)\end{array}$ \\
\hline $\begin{array}{c}Y= \\
D_{95 / 96} X^{2}\end{array}$ & & & & $\begin{array}{c}-0.017 * * \\
(0.0953)\end{array}$ \\
\hline \multicolumn{5}{|l|}{$\begin{array}{c}Y= \\
D_{95 / 96} X^{3} \\
\end{array}$} \\
\hline$R^{2} \mathrm{adj}$. & 0.053 & 0.416 & 0.217 & 0.511 \\
\hline$F$-Stat & $3.999 * * *$ & $39.291 * * *$ & $15.890 * * *$ & $51.190 * * *$ \\
\hline Num. Obs. & 914 & 914 & 914 & 914 \\
\hline Num.Coeff. & 18 & 18 & 18 & 20 \\
\hline
\end{tabular}

Note: values in parentheses are the prob-values of the $t$-statistic and $F$-statistic, respectively. Estimation results for the intercept and 15 dummy-variables for each year and region are not reported here. They are available in Fink and Koller (2001).

$* * *, * *$ and $*$ denote statistical significance at confidence levels of $0.1,1$ and 5 percent. 


\section{Figure 1}

Development of cash-flow performance 1989-1996, retail trade, wholesale trade sector and overall economy

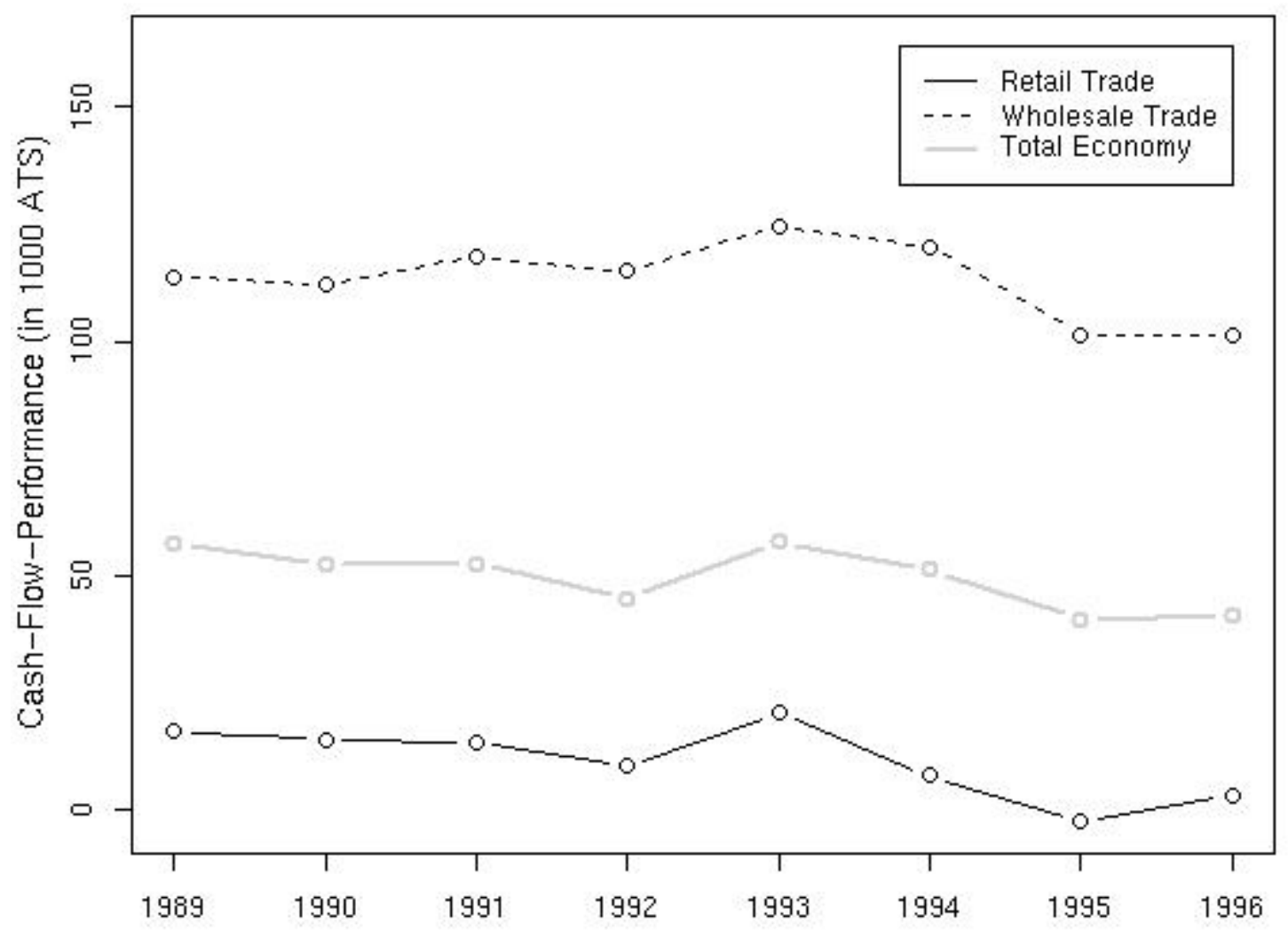




\section{Figure 2}

\section{Estimated relationship between firm size and cash-flow performance}

a) Retail trade

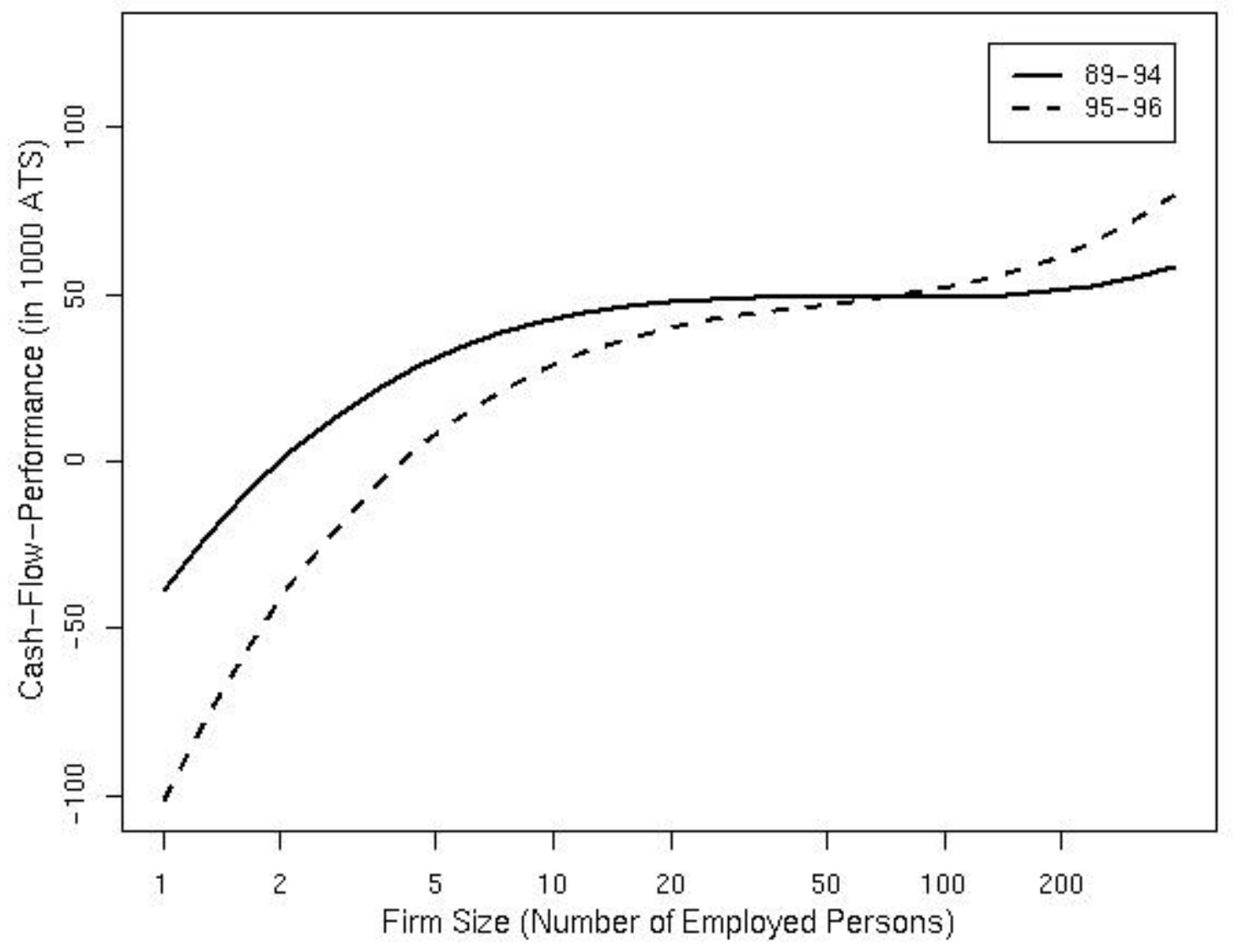




\section{b) Wholesale trade}

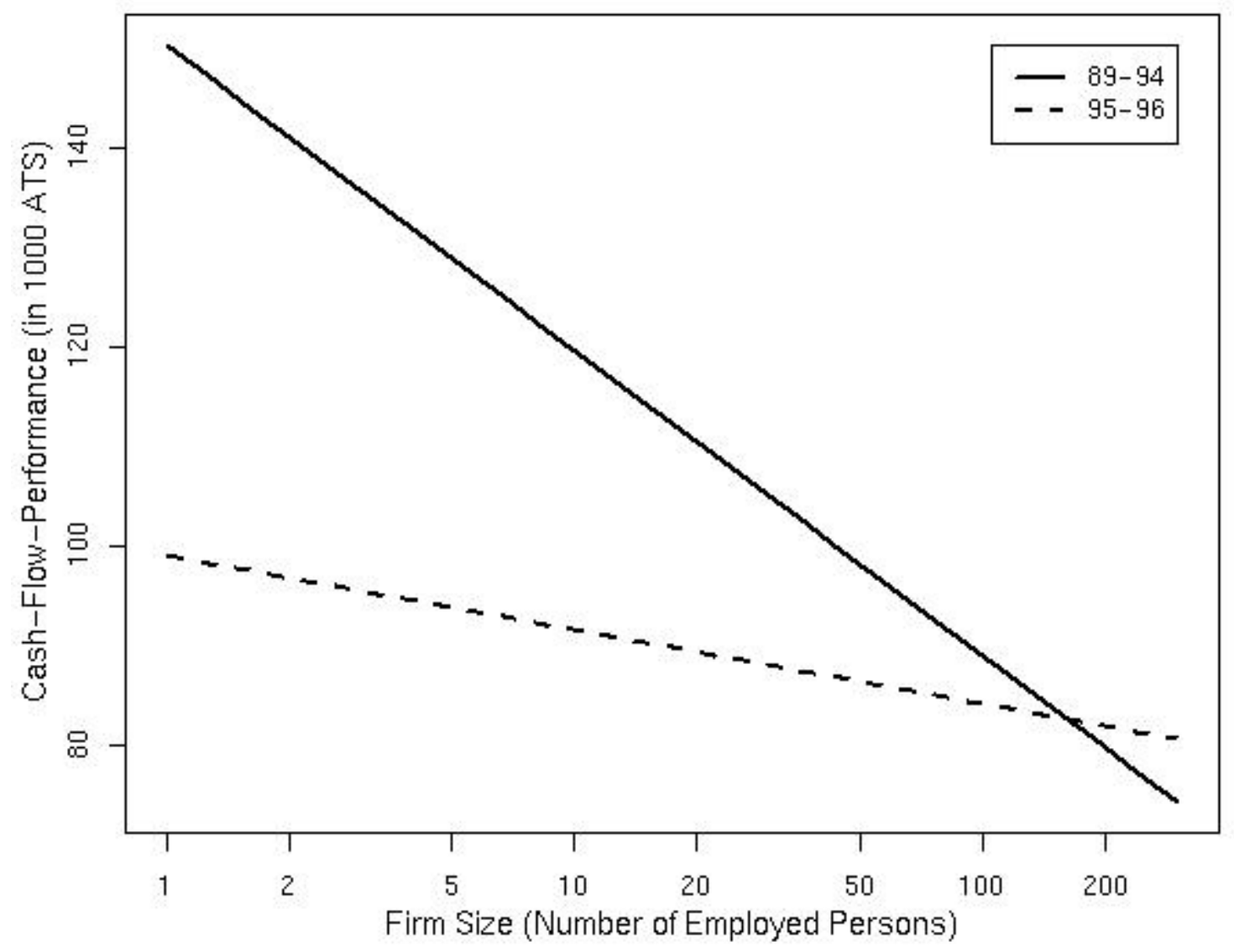




\section{Figure 3}

\section{Estimated relationship between firm size and cash-flow-risk}

a) Retail trade

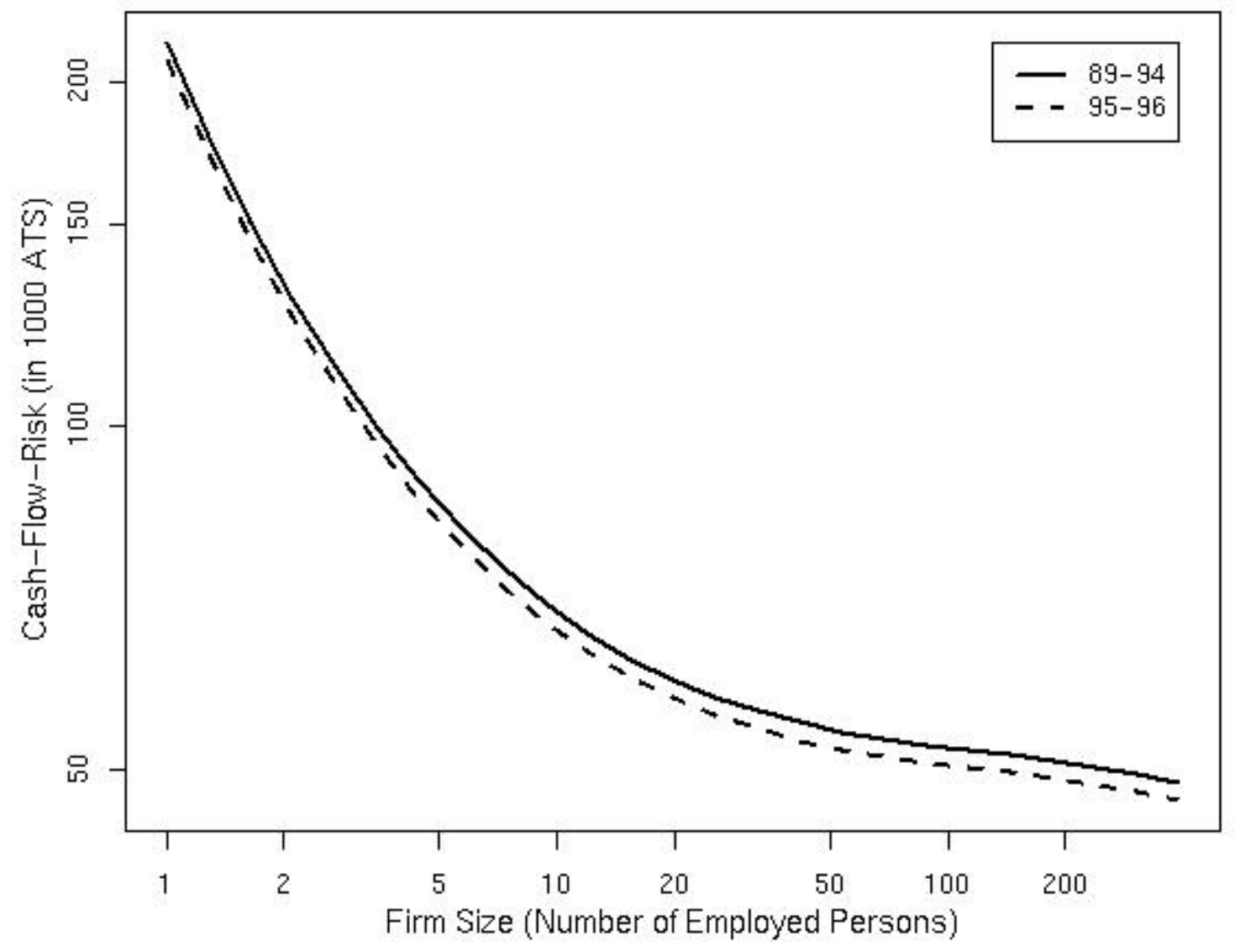


b) Wholesale trade

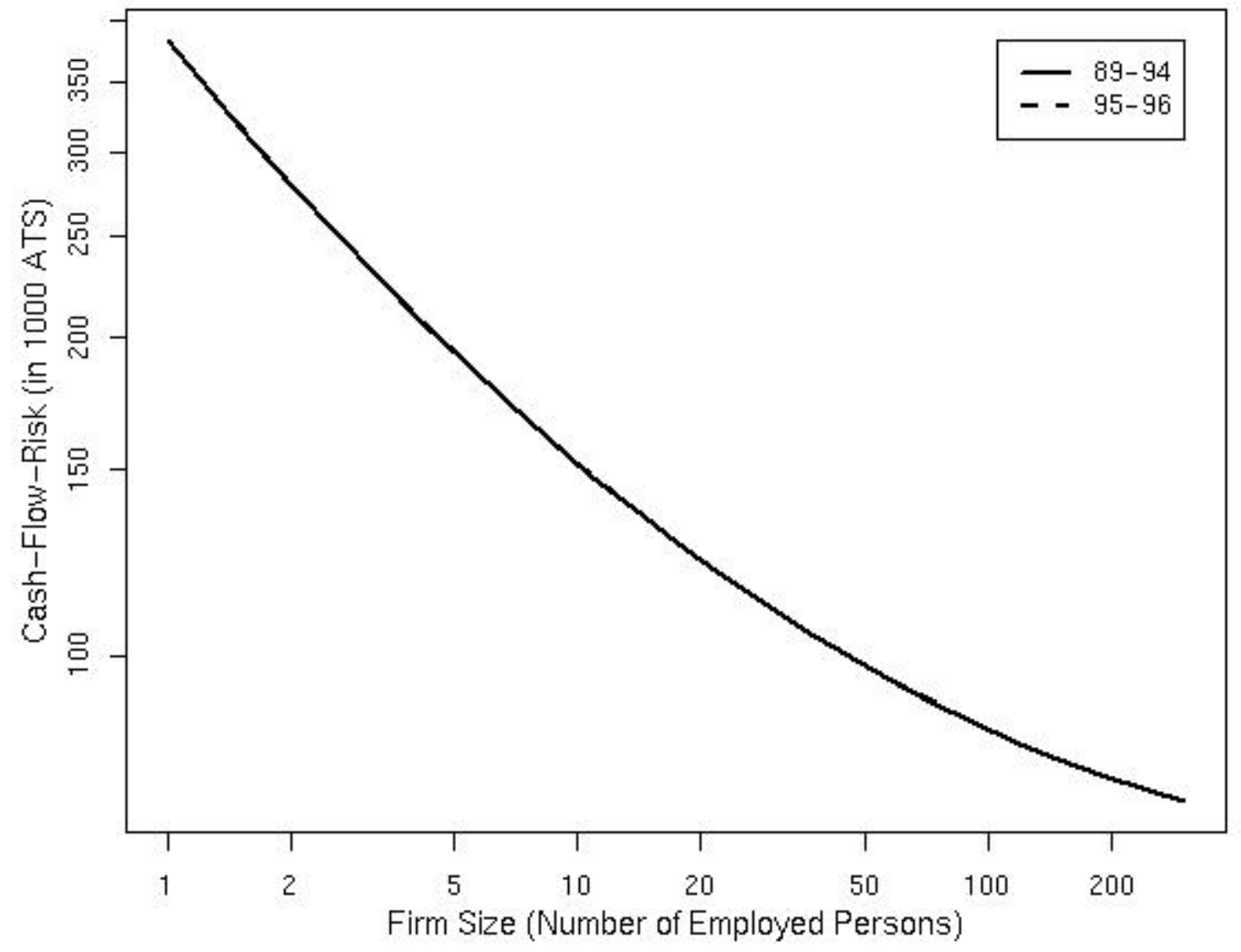

http://eiop.or.at/eiop/texte/2002-009t.htm 


\section{Figure 4}

\section{Estimated relationship between firm size and financing cost}

a) Retail trade

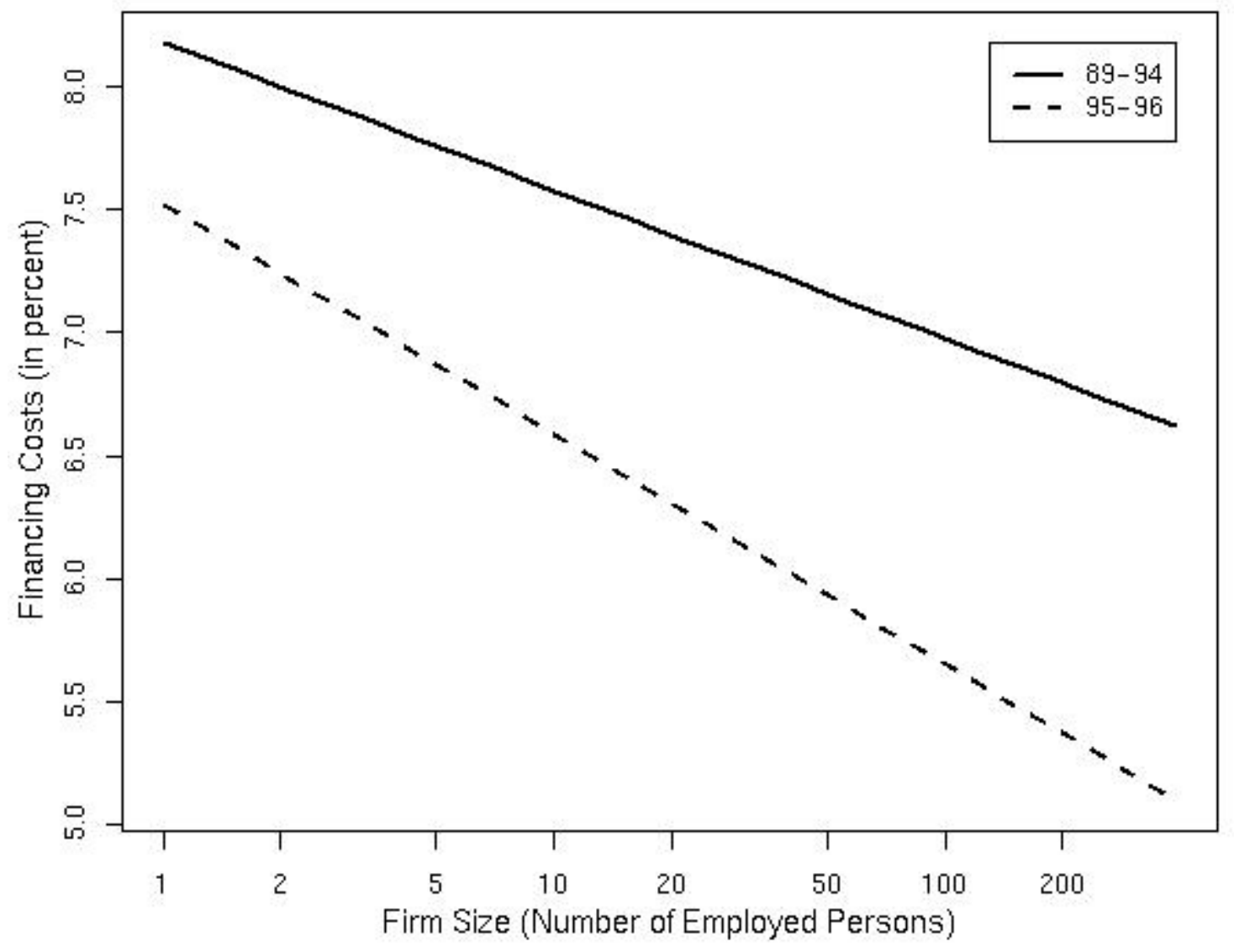




\section{b) Wholesale trade}

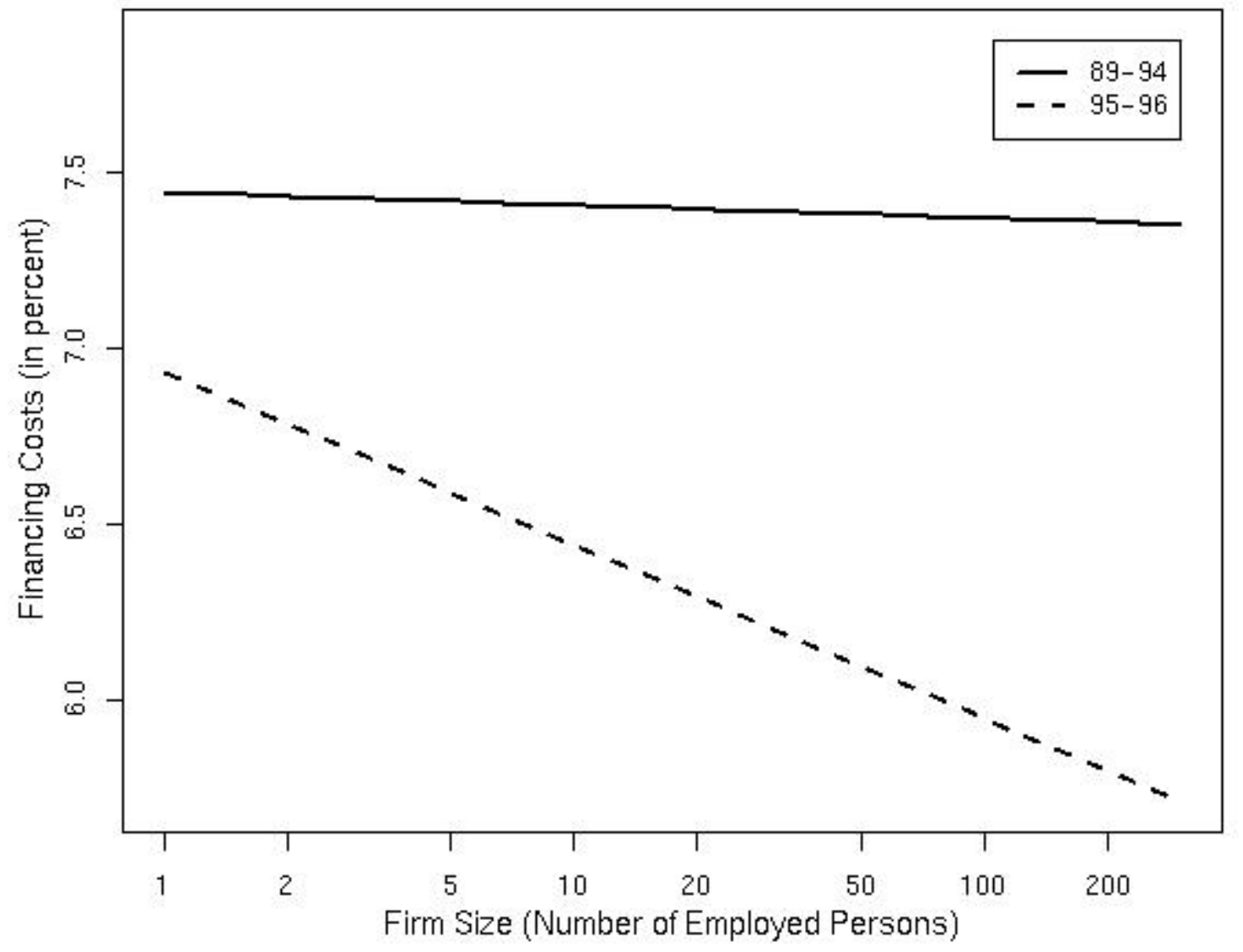




\section{Figure 5}

Estimated relationship between firm size and per capita debt

a) Retail trade

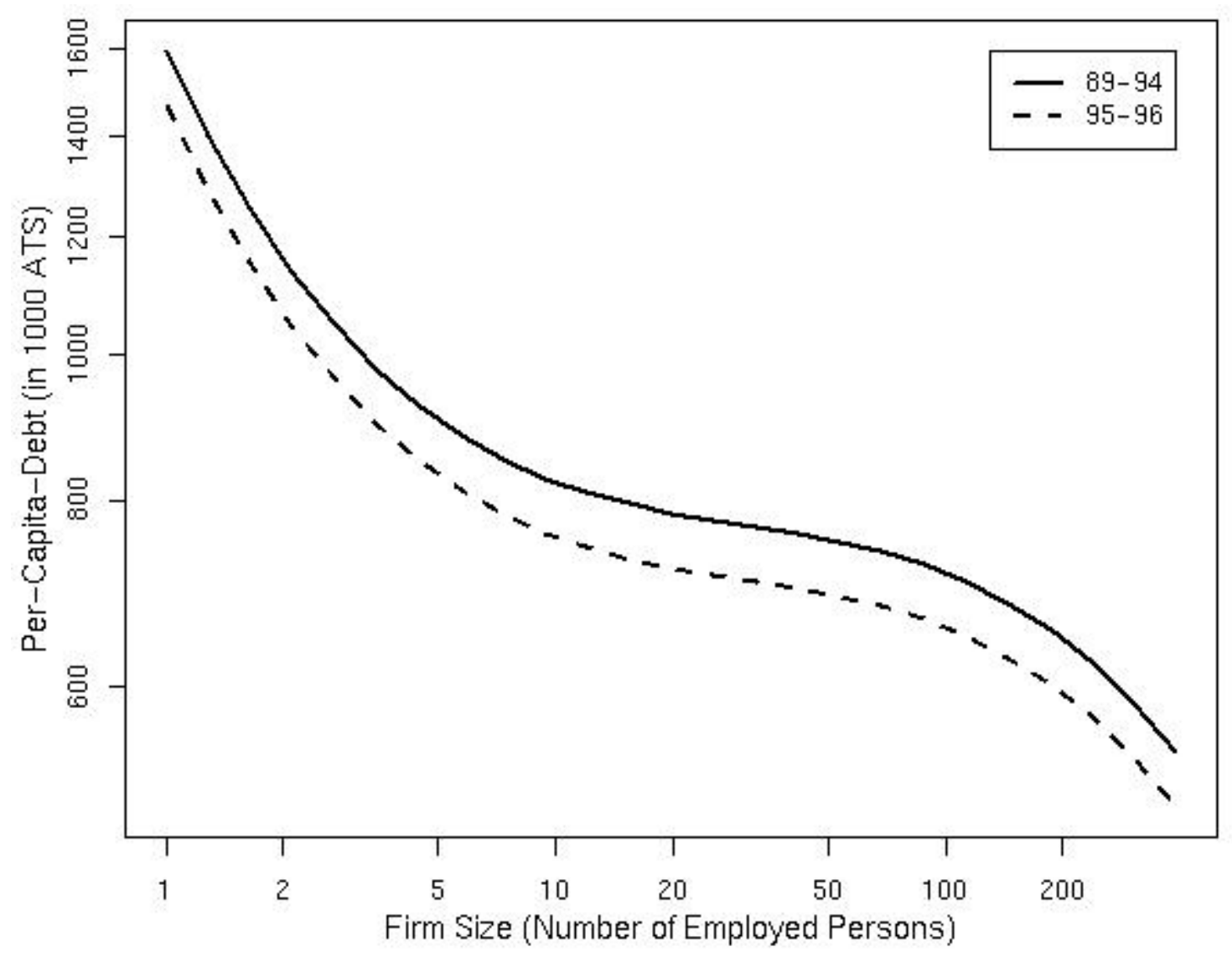




\section{b) Wholesale trade}

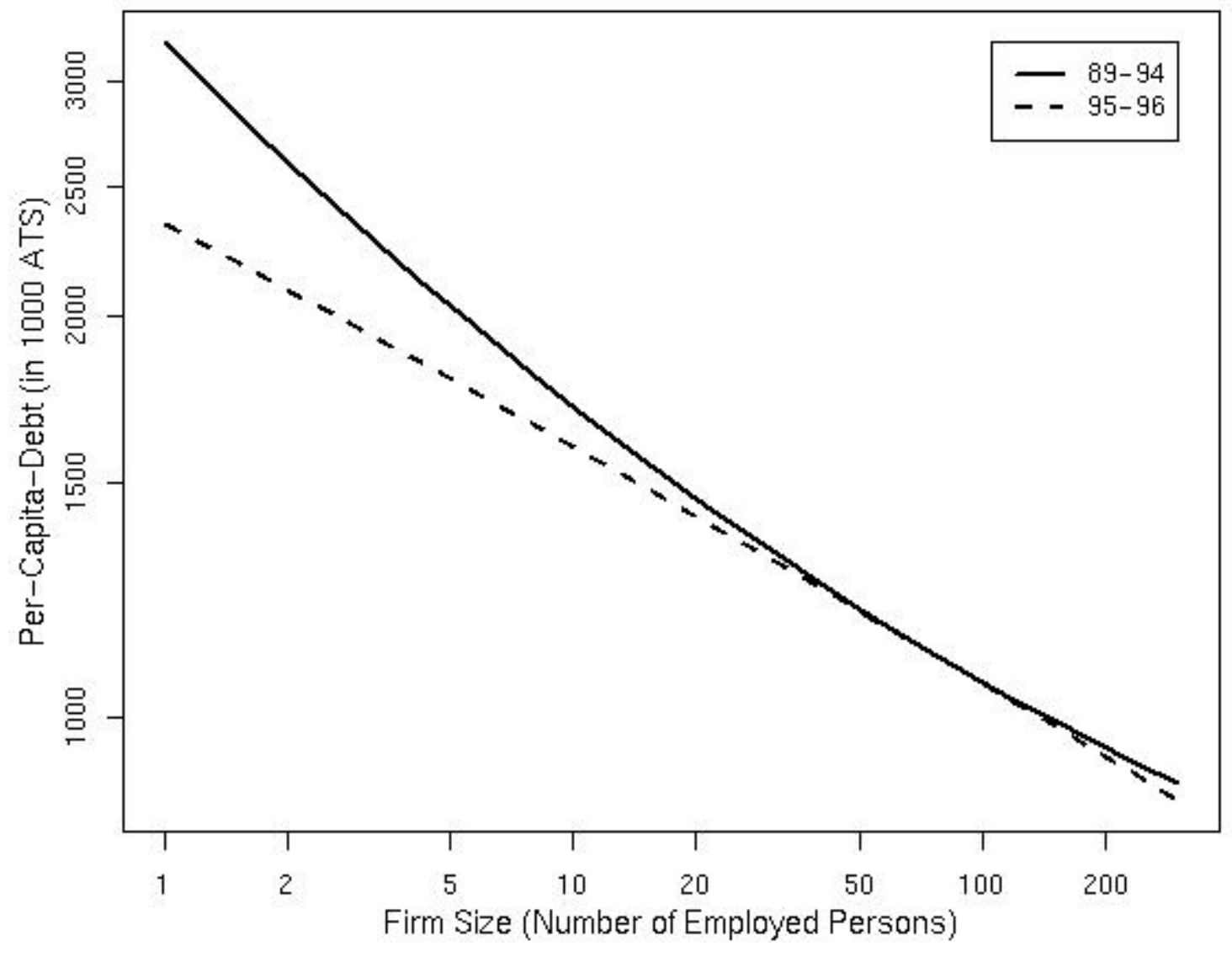

(C)2002 by Fink \& Koller

formated and tagged by S.H., 16.7.2002 